\title{
Typochronologie de la céramique médiévale dans l'espace normand : production, diffusion
}

\section{Anne Bocquet-Liénard}

\section{OpenEdition \\ Journals}

Édition électronique

URL : http://journals.openedition.org/adlfi/16835

ISSN : 2114-0502

Éditeur

Ministère de la culture

Référence électronique

Anne Bocquet-Liénard, « Typochronologie de la céramique médiévale dans l'espace normand production, diffusion », ADLFI. Archéologie de la France - Informations [En ligne], Basse-Normandie, mis en ligne le 15 mars 2016, consulté le 23 avril 2019. URL : http://journals.openedition.org/adlfi/16835

Ce document a été généré automatiquement le 23 avril 2019

(C) Ministère de la Culture et de la Communication, CNRS 


\title{
Typochronologie de la céramique médiévale dans l'espace normand: production, diffusion
}

\author{
Anne Bocquet-Liénard
}

Lien Atlas (MCC) :

1 Depuis 2008, le PCR œuvre à la mise en place d'une typochronologie de la céramique médiévale et moderne en Normandie. L'année 2013 a été consacrée à la lecture critique de la base documentaire rassemblée pour les sites de Haute-Normandie. Ce travail a permis d'enrichir, d'évaluer et de cartographier les lots disponibles pour la constitution du répertoire de formes pour les $\mathrm{XI}^{\mathrm{e}}$-XII $\mathrm{e}$. Celui-ci a été proposé à partir des lots céramiques ayant fourni une étude, une datation fiable et des formes archéologiquement complètes. Après son élaboration en région, des correspondances sur l'ensemble de la Normandie ont été examinées. Deux ateliers de potiers de la période concernée ont été échantillonnés en vue d'une étude physico-chimique des productions (Acquigny dans le département de l'Eure et Gournay-en-Bray dans le département de la Seine-Maritime).

2 Pour la Basse-Normandie, tous les lots $\mathrm{du} \mathrm{XI}^{\mathrm{e}-\mathrm{XII}}{ }^{\mathrm{e}} \mathrm{s}$., y compris ceux présentant de la céramique fragmentée, ont été réexaminés afin d'affiner la périodisation et de compléter les diverses observations, en particulier les groupes techniques. Des notices synthétiques ont été réalisées à partir de l'examen des données typologiques et macroscopiques (pour le département de la Manche: Cametours, site des Fournaises et Colomby, site de la Perruque; pour le département de l'Orne: la Poterie de Sées). L'examen de ces lots a permis de compléter le répertoire de formes pour le $\mathrm{XI}^{\mathrm{e}}-\mathrm{XII}^{\mathrm{e}} \mathrm{s}$. En ce qui concerne les groupes techniques, l'ensemble des céramiques datées $\mathrm{du} \mathrm{xI}^{\mathrm{e}}-\mathrm{XII}{ }^{\mathrm{e}} \mathrm{s}$. ont fait l'objet d'une caractérisation macroscopique en utilisant la méthodologie mise en place en 2009, publiée en 2013 (Dervin, Hanusse et Bocquet-Liénard, 2013, Revue archéologique de Picardie, p. 161-174). La définition des groupes techniques repose sur l'observation de la pâte et des caractères techniques liés à la fabrication de l'objet (traitement de surface par exemple). 
Un catalogue des groupes techniques pour les $\mathrm{XI}^{\mathrm{e}}-\mathrm{XII}^{\mathrm{e}} \mathrm{s}$. a été proposé pour la région basnormande. La mise en place de ce catalogue par période chronologique a pour objectif d'identifier et de caractériser des productions distinctes mais aussi d'analyser les évolutions techniques et culturelles au cours du temps.

3 Les travaux du collectif se poursuivront en 2014 par l'établissement du répertoire des XIII -XIV ${ }^{\mathrm{e}}$ s. pour toute la Normandie.

INDEX

Index géographique : Basse-Normandie, Calvados (14)

Index chronologique : Moyen Âge, Temps Modernes

operation Projet collectif de recherche (PCR)

Mots-clés : céramique

\section{AUTEURS}

ANNE BOCQUET-LIÉNARD

SUP 